\title{
Agromorphological characterization of some rice species in the main rice cropping area of Chad
}

\author{
Bouré Ouéyé GAOUNA ${ }^{1,2^{*}}$, Moupeng BIDJAOUEYE ${ }^{3}$, Romaric Kiswendsida NANEMA ${ }^{2}$, \\ Gapilli NAOURA $^{2}$ and Jean-Didier ZONGO ${ }^{2}$
}

${ }^{I}$ Institut Tchadien de Recherche Agronomique pour le Développement (ITRAD), B.P. 5400, N'Djaména, Tchad; Tél. : +23530589 99/+2352520101. E-mail : salut.boure@ gmail.com;

${ }^{2}$ Laboratoire de Génétique et de Biotechnologie Végétales, Unité de Formation et de Recherche en Sciences de la Vie et de la Terre, Université de Ouagadougou, 09 BP 848 Ouagadougou 09, Burkina Faso ; E-mail : nanemaromaric@yahoo.frou romaric_nanema@univ-ouaga.bf ;

${ }^{3}$ Université de N'Djaména, Département de Géographie, Tchad ; E-mail : m_bedjaoue@yahoo.fr

*Corresponding author, E-mail: salut.boure@gmail.com, Tel: +23563058999.

\begin{abstract}
Rice is the basic cereal of the populations of the areas of Tandjile and Western Mayo Kebbi, in the south of Chad. The rice productivity is, however, low: less than $1 \mathrm{t} / \mathrm{ha}$. This is related to several factors, of which the strong infestation of rice plantation into adventitious and lack of improved varieties with high productivity. Among the bad frequent grasses, harmful for cultivated rice, the species like Oryza sativa, Oryza barthii and Oryza longistaminata show the strong dynamic ones of infestation in the rice plantations of flooded plains of the areas of Tandjilé and Western Mayo Kebbi. The agromorphological characterization of the samples of the prospection-collection from October 2005 to Mars 2006 revealed the existence of three types of rice in the zone: wild rice, adventitious rice and cultivated rice. The group of cultivated rice breaks up into three pennies groups on the basis of duration of sowing-heading cycle. The objective of this study was to characterize the agromorphological features of these groups.

(c) 2011 International Formulae Group. All rights reserved.
\end{abstract}

Keywords: Rice cropping area, Tandjilé and Western Mayo-Kebbi, Chad, weedy rice and genetic.

\section{INTRODUCTION}

Several centuries ago, man's activities in Chad included the use of various rice species. Nowadays, the main rice species found in Chad are identified as: Oryza barthii, A. CHEV.; O. breviligulata A. CHEV.; O. glaberrima S.T. and O. sativa L., $O$. barthii and $O$. breviligulata, known as wild species, are mainly found at the edge of rivers, lakes, or in their zones of flood (Logone river valley, Chari river valley, Mandoul river and Lake Fitri). These rice species were gathered everywhere before the massive introduction of the cultivated rice species. Wild rice, $O$. glaberrima S.T, was just discovered very recently in "Casier A" of Bongor area and would have been introduced accidentally from West Africa. Oryza sativa L, the cultivated rice species, was introduced in Chad in a more or less anarchistic way for several centuries. But its massive adoption was done since 1940. In addition to these rice species, other types of rice would have appeared with new introduction of $O$. sativa $\mathrm{L}$, either from the 
surrounding countries (Cameroun, Nigeria, Central Africa, etc), or Asian countries (China, etc), or through international assistance in the form of seed-bearer assistances following the years of dryness during which rice production was almost null. Therefore, it arises a serious problem in the rice cropping area of Chad: these new types of "non-cultivated rice", spontaneous in the rice cropping area, very invading and very competitive rice, constitute relatively significant constraints with the production of cultivated rice. Many farmers have to give up their rice fields because of these weedy rice species. However, technical control of weedy rice species is still a challenge and the problems of weedy rice remain intact and without sustainable solutions. Initially there are species relatively badly known and little characterized. It seems that most of the rice known as weedy rice species are Oryza types and even of the sativa species. The damage caused by these weedy rice species in the rice exploitations is enormous, at least in the zone corresponding to our study area. Owing to the fact that the majority of weedy rice species are shelling and that the strong competitiveness of these weedy rice species is very significant, farmers in this rice cropping area could get loss of yield which can go from 25 to $100 \%$ (Gaouna et al., 2006). Shelling rice or red rice is a bad grass in the biotope of cultivated rice (Oryza sativa L.) and which can be distinguished from the rice cultivated only after stem elongation, mainly because of the high straw and the thinness of the stems of the seedlings, significant tillering and the greener sheets. At maturity, the grains are detached from the panicle and fall into the ground before the harvest of cultivated rice. This operation accelerates the dissemination of the adventitious grains which enriches stock by the adventitious grains of the ground (Smith, 1981; Diarra et al., 1985a; Diarra et al., $1985 b)$. The adventitious dispersed rice grains can remain in the ground in condition of dormancy for more than two years (Ferrero and Vidotto, 1997). The variety of adventitious rice is more spread in the world than the variety $O$. sativa L. Var. Sylvania (Parker and Dean, 1976; Ferrero and Finassi, 1995). Weedy rice has always occurred in the main rice cropping area in Chad at low population levels. Over the last 10 years, the intercropping period was reduced due to more extensive rice production. At the same time, weedy rice populations and the number of infested rice fields have increased, becoming a serious rice production problem (Gaouna et al., 2005). The term "weedy rice" refers to populations of usually annual Oryza species that diminish farmer's income both quantitatively through yield reduction, and qualitatively, through lowered commodity value at harvest. Weedy rice occurs in all the major rice growing areas in the world, particularly in tropics, being a particular problem in direct seeded rice agriculture of regions like Latin and North America, the Caribbean, Africa, South and South East Asia (Oka, 1988). Weedy rice occurs where conditions of direct seeding and intensive production prevail (Bres-Patry et al., 2001). Weedy rice may have indica or japonica characteristics and show weedy traits such as phenotypic plasticity, a high seed dispersal ability and seed dormancy. Weedy rice seeds usually have a red pericarp (thus commonly called "red rice"), earlier tillering plus flowering than cultivated rice, and anthocyanin pigmentation of different plant parts, such as, collar, ligula, grain apiculus, stigma and awns (Cho et al. 1995; Suh et al. 1997). The objective of this work was to point out rice agromorphological variabilities of the main ecology area in Chad.

\section{MATERIALS AND METHODS Materials}

A set of rice species samples, collected from October 2005 to March 2006 (Gaouna and Djingué, 2007), was used to set up trials. Figure 1 presents the origin of the collected samples. Samples were divided into three batches each one, and conditioned in bags characterized by: (1) a number; (2) source of the sample (locality); (3) variety or the species.

\section{Agromorphological evaluation}

The experimentation purpose was the agromorphological characterization of various species and varieties of rice. This experimentation was carried out in two sites: 
site of Mala/Laï and site of Gassi/N'Djaména. After verification of information on the local names of the various rice varieties and species of Chad, 405 varieties and species of rice were finally retained for the study of agromorphological characterization.

Conditions of culture: preparatory and installation work of the experimental piece was carried out in the following way: (1) Ploughing and preparation of the beds of seeds; (2) vegetable Material: 405 varieties and species of rice in Chad; (3) Delimitation of the ground, staking (from the $2^{\text {nd }}$ to $7^{\text {th }}$ July for Mala and $10^{\text {th }}$ to $11^{\text {th }}$ July for Gassi). The ground of experimentation, in each site, had as dimensions: $135 \mathrm{~m}$ length and width of $10 \mathrm{~m}$, with thus a total surface of $1350 \mathrm{~m}^{2}$. The piece is organized in the following way: (1) Three repetitions separated by $1 \mathrm{~m}$ alley; (2) Each species/variety is sown on two lines of $6 \mathrm{~m}$ length; (3) $15 \mathrm{~cm}$ between seed holes and 15 $\mathrm{cm}$ between the lines.

\section{Qualitative characteristics}

Tables 1 and 2 below give respectively the qualitative and quantitative characteristics and the corresponding methods used.
The quantitative characteristics observations were done in the following mode: (1) a labelling of 2 feet per repetition: (2) Several statements per foot.

\section{Data analysis}

The collected data and observations made on the various ecotypes were treated with the software Excel and XLSTAT-Pro 7.1. The Excel software made it possible to produce histograms of distribution of the ecotypes for some quantitative variables. Other analyses were carried out with XLSTAT-Pro 7.1. The analysis of variance (ANOVA), analyzes plain-varied, was carried out for quantitative variables. This analysis aimed at evaluating the level of variability of the material and identifying the descriptors; the study of the relations between the characters was carried out thanks to the correlations and the analysis of the multiple components (AMC); a study of the organization of variability by the hierarchical ascending analysis (HAA); the groups formed by the Ascending hierarchical clustering (AHC) were characterized by the discriminating factorial analysis (DFA).

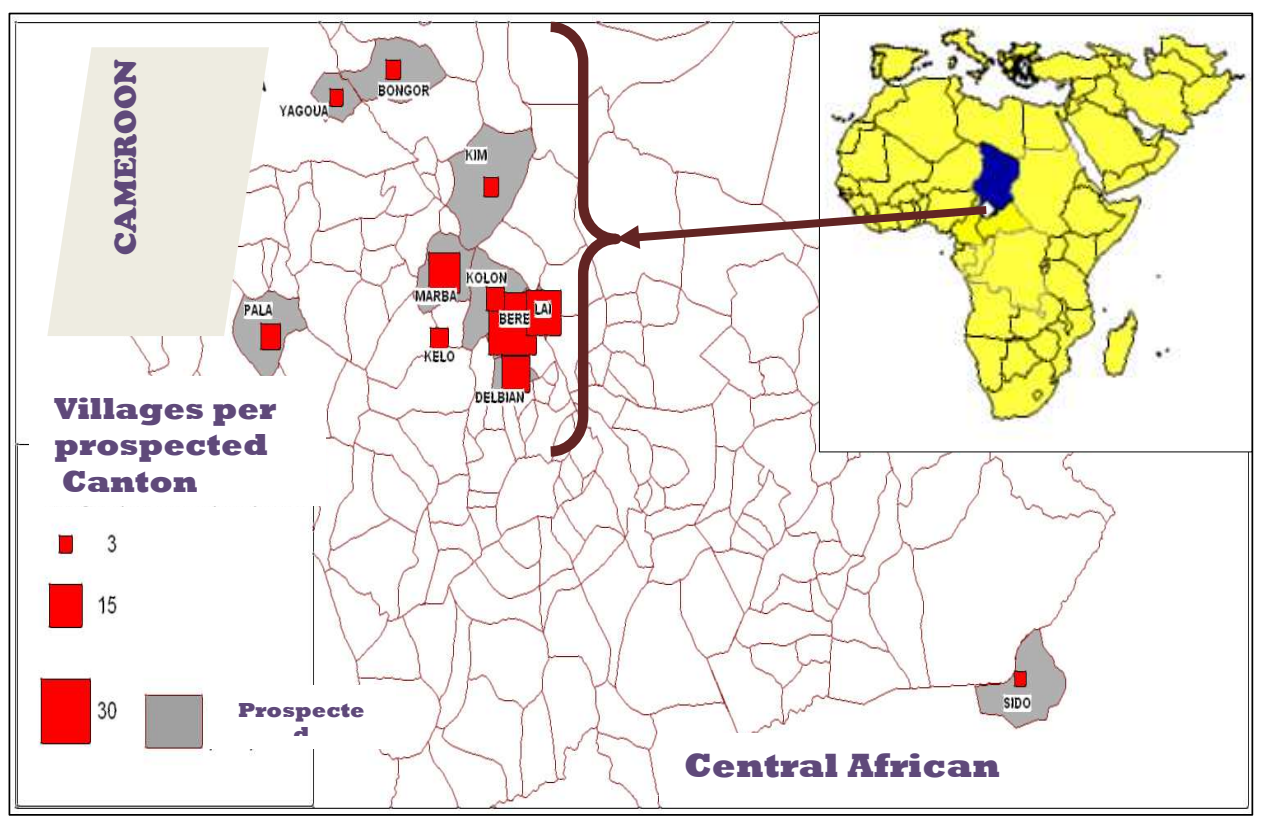

Figure 1: Map of the prospection zones and rice species collection areas of South Chad. 
Table 1: Qualitative characteristics observed and corresponding variants.

\begin{tabular}{|c|c|c|}
\hline $\mathbf{N}$ & The wording of the characteristics and the variants & Codes \\
\hline \multirow{3}{*}{1} & Uniformity of the population & POPUNI \\
\hline & - Homogeneous & $-\mathrm{H}$ \\
\hline & - Heterogeneous & $-\mathrm{h}$ \\
\hline \multirow[b]{2}{*}{2} & Effective sowing date & DES \\
\hline & & - qo \\
\hline \multirow{4}{*}{3} & Length of the cycle of life & DCV : \\
\hline & - Annual & $-\mathrm{A}$ \\
\hline & - Perennial & $-\mathrm{P}$ \\
\hline & - Intermediary & $-\mathrm{I}$ \\
\hline \multirow{6}{*}{4} & Duration:beginning of the cycle (C) $-80 \%$ maturity & DCS80\%MAT \\
\hline & - $\quad \mathrm{C}<90 \mathrm{j}:$ Very early & $-\quad \mathrm{Tpr}$ \\
\hline & - $90<\mathrm{C}<100$ : Early & $-\quad \mathrm{Pc}$ \\
\hline & - $100<\mathrm{C}<120$ : Means & $-\mathrm{Mn}$ \\
\hline & - $120<\mathrm{C}<130$ : Late & $-\quad \mathrm{Tf}$ \\
\hline & - C > 130: Very Late & $-\quad$ TTf \\
\hline \multirow{6}{*}{5} & Coleoptiles: anthocyanin Colouring & CAntClp : \\
\hline & - Absent & $-\mathrm{O}$ \\
\hline & - $\quad$ Very weak & $-\quad \mathrm{Tf}$ \\
\hline & - Weak & $-F$ \\
\hline & - $\quad$ Means & $-\quad M$ \\
\hline & - Extremely & $-\mathrm{Ft}$ \\
\hline \multirow{5}{*}{6} & Color of the base of the sheet: & BLSC : \\
\hline & - Green & $-\mathrm{V}$ \\
\hline & - Green with lines crimsons & $-\quad V p$ \\
\hline & - Clear crimson & $-\mathrm{Pc}$ \\
\hline & - Crimson & $-\mathrm{Pp}$ \\
\hline \multirow{5}{*}{7} & Anthocyanin color of the sheet & LSAC : \\
\hline & - Absent & $-\mathrm{O}$ \\
\hline & - Weak & $-\mathrm{F}$ \\
\hline & - $\quad$ Means & $-\quad M$ \\
\hline & - Strong & $-\mathrm{Ft}$ \\
\hline \multirow[b]{3}{*}{8} & Limb of the sheet: presence/absence of anthocyanin coloring: & LBP/AAC : \\
\hline & - Absent & $-\mathrm{A}$ \\
\hline & - Present & $-\operatorname{Pr}$ \\
\hline \multirow{4}{*}{9} & Limb of the sheet: position vs its bases: & LBA : \\
\hline & - Set up & $-E$ \\
\hline & - Horizontal & $-\mathrm{Hr}$ \\
\hline & - Drooping & $-\mathrm{Tb}$ \\
\hline \multirow{4}{*}{10} & Limb of the sheet: pubescence & LBP: \\
\hline & - Clean shaven & $-\mathrm{G}$ \\
\hline & - Intermediary & $-\quad \mathrm{I}$ \\
\hline & - Pubescent & $-\mathrm{Pu}$ \\
\hline
\end{tabular}




\begin{tabular}{|c|c|c|}
\hline 11 & $\begin{array}{l}\text { - } \quad \text { Set up } \\
\text { - Semi-set up (intermediate) } \\
\text { - Horizontal } \\
\text { Downward }\end{array}$ & $\begin{array}{ll}- & \mathrm{E} \\
- & \mathrm{Se} \\
- & \mathrm{He} \\
- & \mathrm{D}\end{array}$ \\
\hline 12 & $\begin{array}{l}\text { Principal stem (Master-bit): position vs the Vertical: } \\
\text { - Set up }\left(<15^{\circ}\right) \\
\text { - Semi-set up (intermediate) }\left(<20^{\circ}\right) \\
\text { - } \text { Blunt }\left(<40^{\circ}\right) \\
\text { - } \text { Deployed }\left(>60-80^{\circ} \text {, the stem is not lying) }\right. \\
\text { ground out (the stem or part of it lying on the surface of the }\end{array}$ & 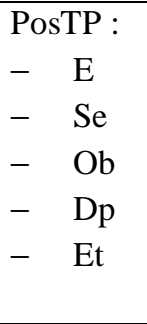 \\
\hline 13 & $\begin{array}{l}\text { Stem: resistance to pours: } \\
\text { - Very weak (all the seedlings fell flat) } \\
\text { - Weak (more the share be seedlings almost fell flat) } \\
\text { - Intermediary (many inclined seedlings with 45) } \\
\text { - Extremely (more the share of the seedlings are tilted to } 20 \mathrm{vs} \\
\text { - } \text { the vertical) } \\
\text { Very extremely (all the seedlings are vertical) }\end{array}$ & 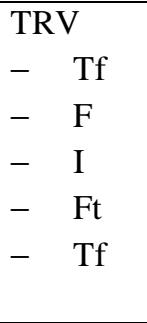 \\
\hline 14 & $\begin{array}{l}\text { Break into leaf: senescence: } \\
\text { - Very early (all the sheets lose their green color before the } \\
\text { - } \text { maturity of the grains } \\
\text { - } \text { Intermediary at least a sheet is always green with harvest) } \\
\text { - Late (at least two sheets remain always green with harvest) } \\
\text { - Very late (all the sheets remained green with harvest) }\end{array}$ & $\begin{array}{l}\text { LfSc: } \\
-\quad \text { Tp } \\
-\quad \operatorname{Prc} \\
-\quad \text { I } \\
-\quad 7 \operatorname{Trd} \\
-\quad 9 \mathrm{Ttr}\end{array}$ \\
\hline 15 & $\begin{array}{l}\text { Panicle: position of the branches: } \\
\text { - Set up (compact panicle) } \\
\text { - Semi-set up (semi-compact panicle) } \\
\text { - Spreading (open panicle) } \\
\text { - Horizontal } \\
\text { - Drooping }\end{array}$ & $\begin{array}{l}\text { PAttBr: } \\
-\quad \mathrm{E} \\
-\mathrm{Se} \\
-\quad \mathrm{Po} \\
-\quad \mathrm{Hr} \\
-\mathrm{Co}\end{array}$ \\
\hline 16 & $\begin{array}{l}\text { Panicle: exertion: } \\
\text { - Locked up (the panicle partially or is entirely locked up in the } \\
\text { sheaths of the sheet paniculaire) } \\
\text { - Exertion partial of the panicle (panicle bases is slightly } \\
\text { beneath the collar of the flag leaf blade) } \\
\text { - Exertion limits (the base of the panicle coincides with the } \\
\text { collet of the sheet paniculaire } \\
\text { - Good moderate exertion (the base of the panicle is with the } \\
\text { top of the collet of the sheet paniculaire } \\
\text { - Good exertion (the base of the panicle appears well with the } \\
\text { top of the collet of the sheet paniculaire) }\end{array}$ & $\begin{array}{ll}- & \text { Enf } \\
- & \text { Epp } \\
\text { - } & \text { Elm } \\
- & \text { Bem } \\
- & \text { Be }\end{array}$ \\
\hline 17 & $\begin{array}{cl}\text { Length }(\mathrm{L}) \text { of the panicular sheet (cultivated species): } \\
\text { - } & \text { Very short }(\mathrm{L}<15 \mathrm{~cm}) \\
\text { - } & \text { Short }(15<\mathrm{L}<20 \mathrm{~cm}) \\
\text { - } & \text { Medium }(20<\mathrm{L}<30 \mathrm{~cm})\end{array}$ & $\begin{array}{l}\text { LPn : } \\
-\quad \mathrm{Tc} \\
-\quad \mathrm{C} \\
-\quad \mathrm{M}\end{array}$ \\
\hline
\end{tabular}




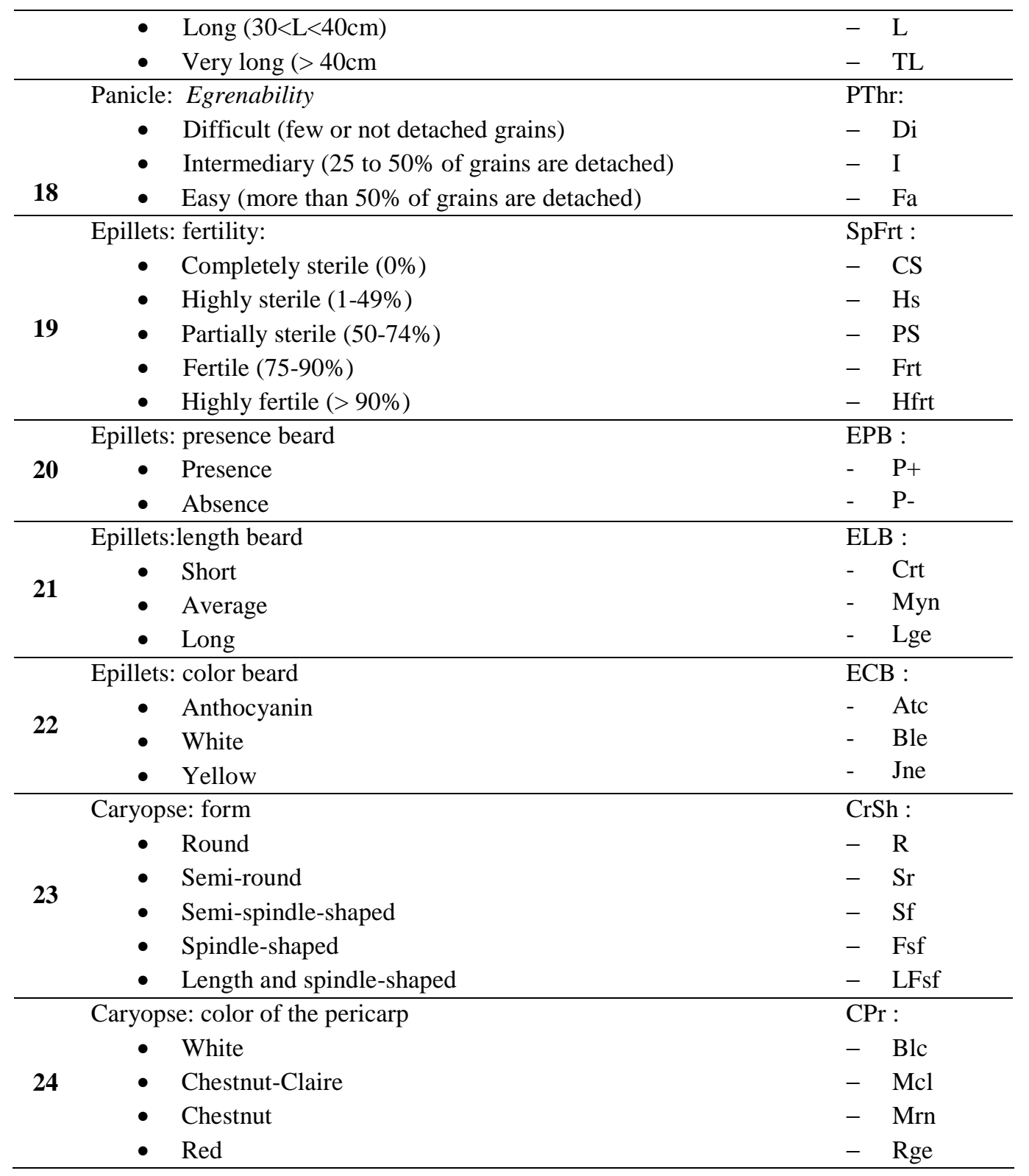

Table 2: Quantitative characteristics measured.

\begin{tabular}{lll}
\hline $\mathbf{N}^{\circ}$ & Wording of the character & Codes \\
\hline 1 & Average height of the seedlings at 20 days after seeding (das) (in $\mathrm{cm})$ & HP20 (cm) \\
2 & Average length of the ligula (mm) & LigLn (mm) \\
3 & Tillers number average at 40 days after seeding & NMT40 jas \\
4 & Duration DES - 1st heading (in days) & DS1E \\
5 & Duration DES - 80\% heading (in days) & DD80\% E \\
6 & Duration DES - 80\% maturity (in days) & DD80\% Mat \\
7 & Panicle: numbers by poquet/plant & PN/Plt
\end{tabular}




\begin{tabular}{lll}
8 & Average length of the stem (in cm) & LTg $(\mathrm{cm})$ \\
9 & Total means of stems per seed hole numbers & NTT/PQt \\
10 & Length of the panicle (in cm) & LPn $(\mathrm{cm})$ \\
11 & Length of paddy (in mm) & LPy $(\mathrm{mm})$ \\
12 & Width of paddy (in mm) & Py $(\mathrm{mm})$ \\
13 & Thickness of paddy (in mm) & $\mathrm{EPy}(\mathrm{mm})$ \\
14 & Average weight of 1000 grains (in $\mathrm{g})$ & $\mathrm{PMG}(\mathrm{g})$ \\
15 & Length of the caryopse (in mm) & LCry $(\mathrm{mm})$ \\
16 & Width of the caryopse (mm) & ECry (mm) \\
17 & Diameter of the principal stem to the 2 nd internode $(\mathrm{mm})$ & DiTP $(\mathrm{mm})$ \\
18 & Length of the sheet under the sheet paniculaire & LavDerF \\
19 & Dispatcher of the sheet under the sheet paniculaire & lavDerF \\
20 & Width report/ratio of the grain/Length paddy & laGrP / LoGrP \\
21 & Yield (Kg/ha) & Rdt $(\mathrm{Kg} / \mathrm{Ha})$ \\
\hline
\end{tabular}

\section{RESULTS}

Genetic variability is defined as being the variation due to the differences in genotypes. It was estimated within the types of rice collected thanks to the analysis of qualitative and quantitative natures. The results of the agromorphological evaluation made it possible to eliminate from the types among the collected samples. These individuals were doubled blooms, due especially to the questions of language and pronunciation, the analysis at the laboratory and the data processing; thus related to the 62 remaining ecotypes.

\section{Analysis of performances of the samples}

Table 3 gives the summary of ANOVA. The analysis of this table emphasizes a highly significant difference between the various samples for all the characteristics. It was noted that the amplitude was high enough for the following characteristics: Average height of the seedlings at 20 das (HP20j), Duration DES-1st exit of ear (DS1E), Duration DES-80\% heading (DS80\% E), Duration DES-80\% maturity (DS80\% Mat), Average length of the stem (LTg), Length of the panicle (LPn), Average weight of 1000 grains (PMG),
Length of the caryopse (LCry) and Yield (Rdt).

\section{Analysis of relationship between traits \\ Correlation between quantitative morphological traits}

This matrix of correlation presents many positively and negatively significant correlations (Table 4).

\section{Associations of characteristics}

The factorial analysis discriminant (FAD) shows that the axis1, which contributes for $90.02 \%$ to inertia, associates the following forms: Thickness of paddy (EPy), Average weight of 1000 grains (PMG), Width of paddy (IPy), Length of the caryopse (LCry), Total means of stems per seed hole numbers (Ntt/Pqt), Duration DES-1st exit of ear (DS1E), Panicle: number by seed hole/plant (PN/plt). The axis 2 of this factorial analysis discriminant contributes for $15.84 \%$ to inertia and associates also the following forms: Average height of the seedlings at 20 jas (HP20j), Tillers number average at 40 jas (NMT40j), Length of the sheet under the panicle sheet (LavDerF), width of the sheet under the panicle sheet (lavDerF), average length of the ligula (LigLn), Length of paddy (LPy) (Figure 2). 
The ascending hierarchical clustering (AHC) obtained from the quantitative traits gives here a dendrogram whose characteristics are as follows: a truncation on level 5.569; this truncation highlights a distribution of seventy five (75) samples in 6 groups (Figure 3). By holding accounts of characters with the formation of nodes, we will note that the subdivision was done on the basis of length of the cycle (Duration DES-80\% heading (in days), DD80\%E).

Figure 4 shows the position of the six groups obtained in AHC in FAD.

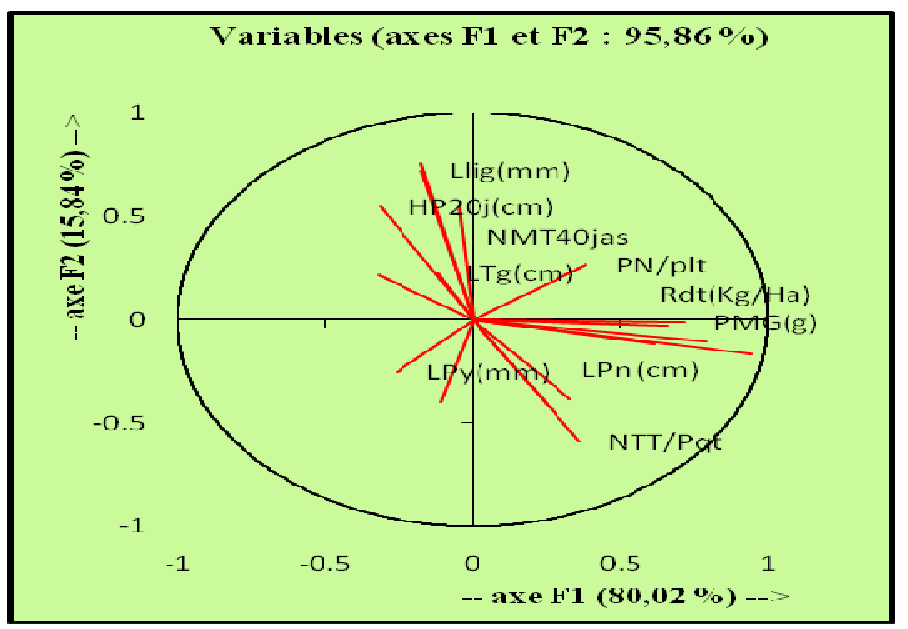

Figure 2: Position of variants of the studied characteristics in FAD.

NMT40 jas: Tillers number average at 40jas; $\operatorname{LTg}(\mathrm{cm})$ : Average length of the stem (in $\mathrm{cm})$; NTT/Pqt : Total means of stems per seed hole numbers; LPn $(\mathrm{cm})$ : Length of the panicle $($ in $\mathrm{cm}) ;$ LPy $(\mathrm{mm})$ : Length of paddy (in $\mathrm{mm}) ;$ PMG $(\mathrm{g})$ : Average weight of 1000 grains (in g) ; Rdt (Kg/ha) : Yield(Kg/ha); Llig (cm) : length of ligula; HP20 (cm): Average height of the seedlings at 20 days after seeding (das) (in cm); PN/Plt: Panicle: numbers by poquet/plant ; Level of truncation of the partition in 6 classes: 5.569 .

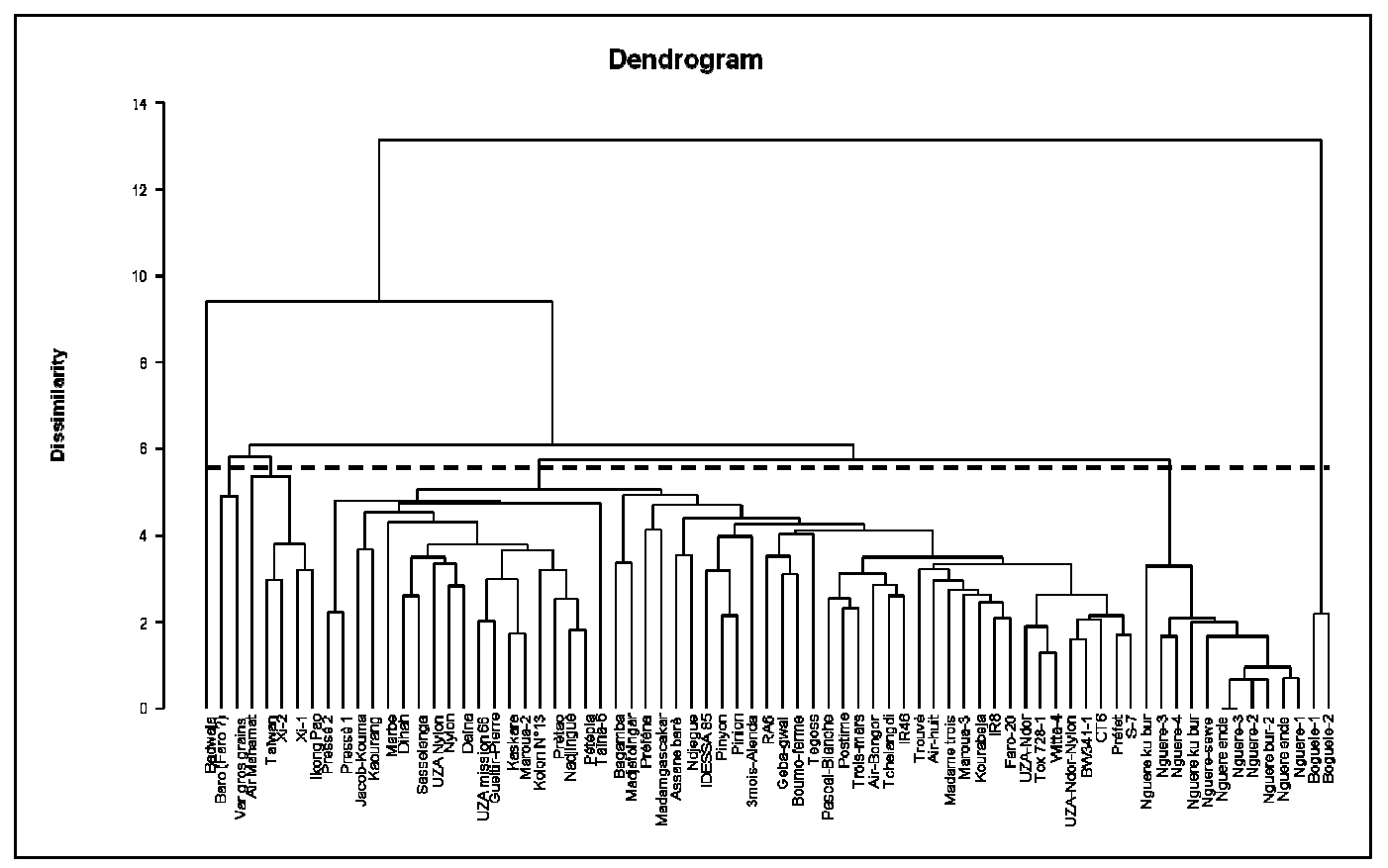

Figure 3: Ascending hierarchical clustering (AHC) carried out on the quantitative variables. 


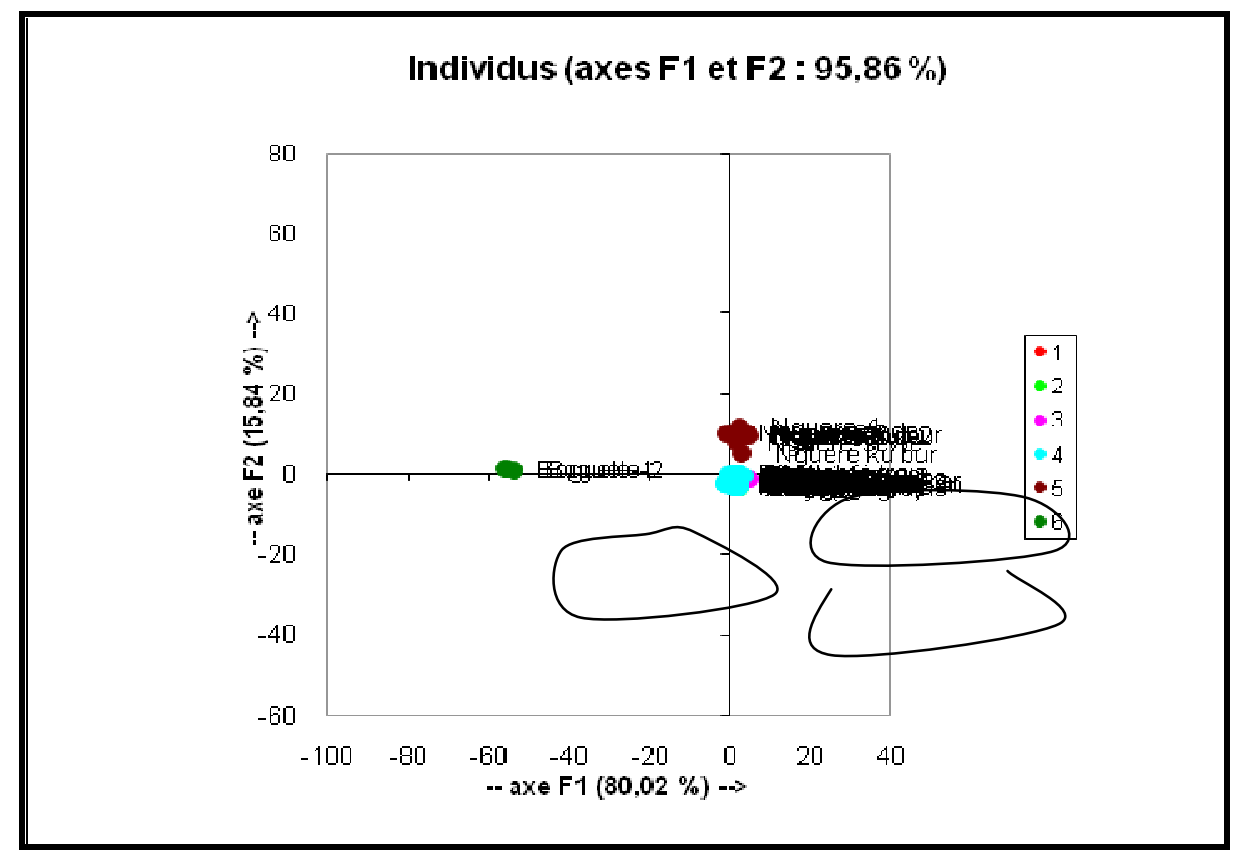

Figure 4: Position of the six groups obtained in AHC in FAD.

Table 3: Average performances and results of the analysis of variance (ANOVA) of rice (Oryza $s p p$ ) of studied area in Chad for the quantitative characteristics.

\begin{tabular}{lcccccc}
\hline Variables & Minimum & Maximum & Average & $\begin{array}{c}\text { Standard } \\
\text { deviation }\end{array}$ & $\begin{array}{c}\text { Coefficient of } \\
\text { variation }(\boldsymbol{\%})\end{array}$ & $\begin{array}{c}\text { Significance } \\
\text { of } \mathbf{~}\end{array}$ \\
\hline HP20j(cm) & 11.7 & 31.33 & 22,482 & 4,295 & 18,91 & $* *$ \\
Llig(mm) & 3.0 & 7.00 & 4,496 & 1,201 & 24,79 & $* *$ \\
NMT40jas & 1.0 & 6.00 & 3,763 & 0,909 & 23,65 & $* *$ \\
DS1E(j) & 51.0 & 106.00 & 76,632 & 11,577 & 14,8 & $* *$ \\
DS80\%E(j) & 62.0 & 117.00 & 87,636 & 11,565 & 12,94 & $* *$ \\
DS80\%Mat(j) & 82.0 & 137.00 & 107,636 & 11,565 & 10,55 & $* *$ \\
PN/plt & 3.0 & $9,7.00$ & 6,491 & 1,524 & 30,9 & $* *$ \\
LTg (cm) & 88.3 & 142.00 & 116,636 & 10,453 & 8,81 & $* *$ \\
NTT/Pqt & 5.0 & 13.67 & 9,803 & 2,024 & 18,49 & $* *$ \\
LPn $(\mathrm{cm})$ & 14.7 & 24.33 & 18,820 & 2,091 & 10,76 & $* *$ \\
LPy(mm) & 6.7 & 10.67 & 8,746 & 0,866 & 9,68 & $* *$ \\
lPdy(mm) & 2.0 & 4.00 & 3,018 & 0,282 & 9,45 & $* *$ \\
EPy(mm) & 0.5 & 2.40 & 2,121 & 0,280 & 13,81 & $* *$ \\
PMG(g) & 10.0 & 31.00 & 23,338 & 2,943 & 13,11 & $* *$ \\
LCry(mm) & 0.0 & 8,67 & 6,610 & 1,345 & 21,21 & $* *$ \\
ECry(mm) & 0.0 & 1.90 & 1,622 & 0,279 & 18,06 & $* *$ \\
DiTP(mm) & 9.0 & 13.00 & 10,781 & 0,828 & 7,88 & $* *$ \\
LavDerF(cm) & 40.0 & 57.67 & 46,482 & 3,895 & 7,71 & $* *$ \\
lavDerF(cm) & 0.6 & 1.13 & 0,828 & 0,137 & 15,1 & $* *$ \\
laGrP/LoGrP & 0.2 & 0.52 & 0,350 & 0,053 & 15,2 & $* *$ \\
Rdt(Kg/Ha) & 0.0 & 3912.00 & 2509,623 & 622,406 & 25,63 & $* *$ \\
\hline$* *$ highly significnt & & & & & \\
\hline
\end{tabular}




\section{B. O. GAOUNA et al. / Int. J. Biol. Chem. Sci. 5(2): 445-460, 2011}

Table 4: Stamp correlation between the studied quantitative characteristics.

\begin{tabular}{|c|c|c|c|c|c|c|c|c|c|c|c|c|c|c|c|c|c|c|}
\hline & $\begin{array}{c}\text { HP20j } \\
(\mathbf{c m})\end{array}$ & \begin{tabular}{|l|l|} 
Llig \\
$(\mathbf{m m})$
\end{tabular} & NMT40jas & $\begin{array}{c}\text { DS1E } \\
\text { (j) }\end{array}$ & PN/plt & $\begin{array}{l}\text { LTg } \\
\text { (cm) }\end{array}$ & NTT/Pqt & $\begin{array}{l}\text { LPn } \\
\text { (cm) }\end{array}$ & \begin{tabular}{|l|l|}
$\mathbf{L P y}$ \\
$(\mathbf{m m})$
\end{tabular} & $\begin{array}{l}\text { IPdy } \\
(\mathbf{m m})\end{array}$ & $\begin{array}{l}\text { EPy } \\
(\mathbf{m m})\end{array}$ & $\begin{array}{l}\text { PMG } \\
\text { (g) }\end{array}$ & $\begin{array}{l}\text { LCry } \\
(\mathbf{m m})\end{array}$ & $\begin{array}{l}\begin{array}{l}\text { DiTP } \\
(\mathbf{m m})\end{array} \\
\end{array}$ & $\begin{array}{c}\text { LavDerF } \\
\text { (cm) }\end{array}$ & $\begin{array}{c}\text { lavDerF } \\
\text { (cm) }\end{array}$ & laGrP/LoGrP & $\begin{array}{c}\text { Rdt } \\
(\mathbf{K g} / \mathbf{H a})\end{array}$ \\
\hline HP20j (cm) & 1 & & & & & & & & & & & & & & & & & \\
\hline Llig (mm) & 0,4951 & 1 & & & & & & & & & & & & & & & & \\
\hline NMT40 jas & 0,120 & 0,268 & 1 & & & & & & & & & & & & & & & \\
\hline DS1E (j) & $-0,473$ & $-0,388$ & 0,276 & 1 & & & & & & & & & & & & & & \\
\hline PN/plt & $-0,118$ & 0,066 & 0,646 & 0,562 & 1 & & & & & & & & & & & & & \\
\hline $\operatorname{LTg}(\mathrm{cm})$ & 0,251 & 0,073 & 0,290 & 0,141 & 0,234 & 1 & & & & & & & & & & & & \\
\hline NTT/Pqt & $-0,548$ & $-0,492$ & 0,004 & 0,738 & 0,559 & $-0,030$ & 1 & & & & & & & & & & & \\
\hline $\operatorname{LPn}(\mathrm{cm})$ & $-0,358$ & $-0,462$ & $-0,055$ & 0,572 & 0,218 & 0,129 & $\mathbf{0 , 5 0 7}$ & 1 & & & & & & & & & & \\
\hline LPy (mm) & 0,137 & $-0,131$ & $-0,087$ & 0,168 & $-0,033$ & 0,232 & 0,163 & 0,301 & 1 & & & & & & & & & \\
\hline lPdy (mm) & $-0,245$ & $-0,103$ & $-0,173$ & 0,081 & 0,070 & $-0,189$ & 0,187 & 0,037 & $-0,222$ & 1 & & & & & & & & \\
\hline EPy (mm) & $-0,379$ & $-0,289$ & $-0,189$ & $\mathbf{0 , 3 3 3}$ & 0,286 & $-0,165$ & 0,396 & 0,273 & $-0,232$ & 0,676 & 1 & & & & & & & \\
\hline PMG (g) & $-0,267$ & $-0,138$ & 0,037 & 0,375 & 0,394 & 0,219 & 0,349 & 0,324 & $-0,175$ & 0,359 & 0,706 & 1 & & & & & & \\
\hline LCry (mm) & $-0,177$ & $-0,213$ & $-0,074$ & 0,428 & 0,398 & 0,023 & 0,451 & 0,431 & 0,349 & 0,453 & 0,743 & 0,603 & 1 & & & & & \\
\hline DiTP (mm) & 0,364 & 0,118 & 0,319 & 0,052 & 0,196 & 0,451 & $-0,045$ & 0,152 & 0,283 & $-0,287$ & $-0,328$ & $-0,124$ & $-0,110$ & 1 & & & & \\
\hline LavDerF (cm) & $-0,061$ & $-0,316$ & $-0,040$ & 0,401 & 0,143 & 0,365 & 0,434 & 0,426 & 0,563 & $-0,153$ & $-0,034$ & 0,096 & 0,216 & 0,447 & 1 & & & \\
\hline lavDerF (cm) & 0,411 & 0,618 & 0,297 & $-0,372$ & 0,027 & 0,201 & $-0,565$ & $-0,474$ & $-0,105$ & $-0,050$ & $-0,281$ & $-0,123$ & $-0,205$ & 0,109 & $-0,339$ & 1 & & \\
\hline laGrP/LoGrP & $-0,248$ & $-0,010$ & $-0,021$ & $-0,057$ & 0,060 & $-0,255$ & 0,012 & $-0,182$ & $-0,817$ & 0,729 & 0,527 & $\mathbf{0 , 3 2 0}$ & $-0,012$ & $-0,353$ & $-0,452$ & 0,014 & 1 & \\
\hline Rdt (Kg/Ha) & $-0,208$ & $-0,150$ & 0,308 & 0,603 & 0,671 & $-0,069$ & 0,552 & 0,277 & $-0,140$ & 0,264 & 0,626 & 0,591 & 0,591 & $-0,055$ & 0,117 & $-0,170$ & 0,252 & 1 \\
\hline
\end{tabular}




\section{Structure of variability}

\section{Classification of the samples}

$F$ value is calculated using the approximation of Rao. Using the results of the Test of Lambda of Wilks (Table 5), we can draw the following conclusion: With the threshold of Alpha $=0.050$ significance, we can reject the null assumption of equality of the vectors hopes of the 6 groups, it means that the difference between the barycentres of the groups is significant.

In comparison with the composition of the group (Table 6), we can, finally consider that there are in reality only 3 groups: (1) group A made up of cultivated species, O. sativa L, the group B which entirely comprises species of weedy rice, mainly $O$. sativa $\mathrm{L}$. and undoubtedly $O$. longistaminata, and the group $\mathrm{C}$ of wild weedy rice, perennial and sterile, with rhizomes. In group A of cultivated rice, we thus distinguished 3 sub-groups, A1, A2 and A3, whose main element of discrimination was the "Duration Sowing-80\% maturity (DD80\% Mat)".

\section{DISCUSSION}

This agromorphological characterization carried out made it possible to rather clearly identify the existence of various rice species in the zone and the appearance of new types of rice, identified as weedy rice.

The genetic diversity of rice is to be considered differently according to zones concerned. When the cultivated and spontaneous forms coexist, there is coupling and co-evolution supported by gene flow and the country selection practices in varied agroecosystems. On the other hand, in Africa, the introduced cultivated shapes of Asia underwent an effect of foundation by migration and were cut flows genic with their parents. Nevertheless, the introduction of Asian rice in Africa and Madagascar did not result in a total reduction in genetic diversity (De Kochko, 1987). The frequency of the intermediate genotypes is more significant and is associated to new morphophysiological types (Miezan and Ghesquière, 1986). The phenomena of hybridization were also very active, maintaining a high diversity and allowing the selection of very many adapted local cultivars (tropical japonica group cultivated into rain, index varieties in flooded zones). The dynamics of the management of these cultivars by the peasants (selection in the zones of contact between the subspecies, exchanges of varieties in the country communities, number of significantly handled cultivars) finally seems to be a guarantee of production in more or less favorable environments and generally not controlled. On the other hand, hybridizations with weedy rices, even if they are possible and identifiable by the isozymic markers seem to be more limited than in Asia, primarily because the reproductive barrier separating Oryza longistaminata is particularly developed (Ghesquière, 1991). In our study area, we noted that almost all the cultivated varieties were Oryza sativa $L$. species although those of the Oryza glaberrima species are practically non-existent, in the traditional rice growing area. The majority of the rice growers in Chad cultivate traditional varieties which are generally tolerant with the pressures of the environment but whose potential of output is lower than that of the improved varieties (Allarangaye et al., 2003). We noted that our results confirm that weedy rice (nguerere...) in our study area, fell into the same cluster as cultivated rice and this suggests that weedy rice evolved from the cultigens (Vaughan et al., 1993). 
Table 5: Test of Lambda de Wilks.

\begin{tabular}{lc}
\hline The wording & Values \\
\hline Lambda & 0,000 \\
F (observed value) & 21,035 \\
F (critical value) & 1,321 \\
ddl 1 & 85 \\
ddl 2 & 265 \\
p-value unilatérale & $<0,0001$ \\
Alpha & 0,05 \\
\hline
\end{tabular}

Table 6: Composition of the groups.

\begin{tabular}{|c|c|c|}
\hline $\begin{array}{l}\text { Classes } \\
\text { (Groups) }\end{array}$ & Size & Composition of the groups \\
\hline 1 & 1 & Badwala \\
\hline 2 & 2 & Baro (Faro ?), Var gros grains \\
\hline 3 & 5 & Air Mahamat ; Xi-1 ; Taïwan ; Xi-2 ; Ikong Pao. \\
\hline 4 & 54 & $\begin{array}{l}\text { Assane barè ; Bagamba ; UZA mission } 66 \text {; UZA Nylon ; IDESSA } 85 \text {; } \\
\text { Marbe ; Pressé } 2 \text {; Madame trois ; RA6 ; Gueltir-Pierre ; Madjetolngar ; } \\
\text { Kolon N¹3 ; Pinyon ; Pinion ; 3mois-Alenda ; Air-huit ; Prètao ; Pascal- } \\
\text { Blanche ; UZA-Ndor ; Kourabeja ; Pressè } 1 \text {; Nylon ; Tchelangdi ; } \\
\text { Préféna ; Dihah ; Ndjegue ; Sasselenga ; Daïna ; Geba-gwal ; Boumo- } \\
\text { ferme ; Postime ; Trois-mars ; Kaskare ; Tegoss ; Air-Bongor ; UZA- } \\
\text { Ndor-Nylon ; Nadjinguè ; Jacob-Kouma ; Maroua-3 ;Trouvè ; } \\
\text { Madamgascakar ; Kaourang ; Maroua-2 ; IR8 ; Pétépia ; Taïna-6 ; Préfet ; } \\
\text { IR46 ; Tox 728-1 ; BW341-1 ; CT6 ; Faro-20 ; Witta-4 ; S-7. }\end{array}$ \\
\hline 5 & 11 & $\begin{array}{l}\text { Nguere ende; Nguere ku bur; Nguere-3; Nguere-4; Nguere ende-2; } \\
\text { Nguere ku bur-2; Nguere-2; Nguere-3; Nguere-sewe ; Nguere bur-2; } \\
\text { Nguere-1 }\end{array}$ \\
\hline 6 & 2 & Boguele-1 ; Boguele-2 \\
\hline
\end{tabular}

Let's remind that universally grown common rice species (Oryza sativa) is of Asian origin and another cultivated rice species (O. glaberrima) is endemic in West Africa. Five wild species share a common AA genome with these two cultivated species: $O$. rufipogon (Asia), O. longistaminata (Africa),
O. barthii (Africa), O. meridionalis (Oceania) and $O$. glumaepatuala (America). Of these, $O$. rufipogon and $O$. barthii are thought to be wild ancestors of Asian and African cultivated rice, respectively. Two cultivated species produce fertile hybrids only with these two wild relatives (Morishima, 1998). 
Domesticated and their wild progenitors have quite contrasting morphological, physiological and ecological traits, though they are genetically very close. Harlan et al. (1973) enumerated common traits carried by domesticated forms, assigning them "adaptive syndromes of domestication". The essential difference between wild and domesticated plants is related to the former's selfreproduction, with the latter reproducing only through human intervention. They involve low seed shedding, rapid simultaneous germination, awnless or short awn and more seed production (Oka 1958, 1988; Morishima et al., 1992). In seed productivity, however, annual wild rice has a $40-60 \%$ harvest index (total seed weight divided by total plant weight) - as high as cultivated rice (Morishima, 1986). This is because annual wild rice depends on seed propagation for survival.

Weedy type rice is frequent in many rice-growing countries, and its characteristics midway between wild and cultivated rice (Tang and Morishima, 1997; Suh, 1997). Weedy rice occurs as natural hybrid populations in wild regions with domesticated borders, and also as weeds in rice fields. These hybrid populations show continuous variation ranging from wild to cultivated types, but usually cannot persist for a long time. But weedy rice adapted to cultivation resembles rice plants and persists longer in rice fields. Farmers in our study area said that the origin of weedy rice was in seeds that came with aide during the drought periods. But we agree with Sano \& Morishima (1982) that there are three possibilities explaining weedy rice origin: 1) transitional from wild to domesticated types (such type must have been abundant in the past, but not now); 2) hybrid derivatives of natural cross between wild and cultivated types (weedy types frequently observed in wild rice distribution area are mostly this type); 3) remnants of ancient cultivars or segregants of natural cross between remotely related cultivated varieties that have been naturally selected for their tolerance to adverse conditions.

These results seem to correspond to those highlighted in Japan, in two prefectures which are Okayama and Nagaro by Maiko et al. (2009). Thus the weedy rice in different rice cropping areas have different characteristics; for example, the pericarp colours of weedy rice in Okayama and Nagano, in Japan, are white and red, respectively (Maiko et al., 2009). We found the same characteristics, in our study area, which give their local names to weedy varieties of rice: "nguerere ku bur" (white weedy rice), "ngerere ku yele" (red weedy rice), "ngerere ku ende" (black weedy rice). However, in both Japan prefectures for example, accessions have an extremely strong seed-shattering habit that occurs rarely in rice varieties; they drop most of their mature seeds before harvesting naturally in the field (Ushiki et al., 2005).

In connection with cultivated rice, no precise historical data could be obtained on the existence of a traditional rice growing formerly at the beginning of the century. However, if it existed, we can affirm that it was not practised on significant surfaces. The local varieties could not thus play a large role in the recent development of the rice growing which used varieties coming, for the majority, from West Africa and Madagascar.

The rice cropping area of the visited zone is very often invaded by a type of plant previously called $O$. breviligulata "adventitious". In these same fields, there is a mixture of $O$. sativa and $O$. glaberrima and we also observed some bearded and sterile plants which are regarded as hybrids between the two cultivated species. Moreover, swarms of intermediate hybrids between $O$. sativa and 
O. glaberrima were observed which resulted probably from "back-cross-country race" on the sterile hybrids "F1". Some of these plants presented all the characters of "adventitious" O. breviligulata but a marked semi-sterility.

We can thus make the assumption that the adventitious forms are, all at least in the area considered, resulting from hybridization between the two cultivated species with backcross-country race by the relative $O$. glaberrima which allows the return to a normal fertility.

\section{Conclusion}

From this agromorphological study, it is known that in the main zone, there are three rice groups: (1)- wild, Perennial and sterile rice, with multiplication by rhizomes; (2)- the adventitious rice, mainly composed of $O$. sativa, but with, very seldom $O$. longistaminata and $O$. barthii; and the group of cultivated rice which is declined in three sub-groups on the basis of essential cycle sowing- $80 \%$ heading.

The most intuitive approach probably rests on the morphology of plants; it is a direct access but presents batches of disadvantages. The techniques developed for the study of genes provide many other possibilities of quantification of diversity. From agromorphological criteria, we noted that in order to characterize them, each accession is sown in the fields. Information can also be given directly by the "data passport" which accompanies each batch by seeds: geographical origin, genealogy, selector, date of inscription to the catalogue (Naville, 2005). Moreover, the use of morphological criteria shows inherent problems: these criteria are finally relatively limited in a number, and the corresponding characters are influenced in a significant way by the environment. What is not the case of the molecular markers, about unlimited numbers; some being independent of the environment. These last years, various techniques based on prints $\mathrm{ADN}$ were used to highlight the existence of various alleles for a given locus and also to arrive to a phylogeny. Microsatellites, or SSR (Simple Sequence Repeat), are one of these techniques. We expect to use the SSRs to establish the phylogeny of the rice species of our study area and to confirm or cancel the structuring of variability like data by the agromorphologic markers. Variation in wild rice is so complex that we need more in-depth studies including hybridization experiments.

\section{ACKNOWLEDGEMENTS}

We thank Dr. Pascal MARNOTTE and Dr. Christian FEAU for their help and support during this study. This work had the financial support of ARS2T/Cooperation Française, N'Djaména (TCHAD); for that, we also thank Dr. Jean VIGNON.

\section{REFERENCES}

Allarangaye MD, Djoulet B, Komna NNG, Vandou B. 2003. Evaluation économique de l'impact de la recherche et de la vulgarisation sur le riz au Tchad. 20p.

Allarangaye MD, Azina GD, Kemtolna M. 1999. Analyse de contraintes paysannes et amélioration variétale participative avec les riziculteurs de Mala-Laï au Tchad. Note interne.

Bres-Patry C, Lorieux M, Clement G, Bangratz M, Ghesquiere A. 2001. Heredity and genetic mapping of domestication-related traits in a temperate japonica weedy rice. Theor. Appl. Genet. 102: 118-126.

Cho YG, Blair MW, Panaud O, McCouch SR. 1995. Cloning and mapping of variety specific rice genomic DNA sequences amplified length fragment polymorphisms (AFLP) from silver-stained 
polyacrylamide gels. Genome, 39: 373378.

Diarra A, Smith JRJ, Talbert RE. 1985a. Growth and morphologicall characteristics of red rice, Oryza sativa L. Weed Sci., 33: 310-314.

Diarra A, R.J. Smith, Jr., and R.E. Talbert. 1985b. Interference of red rice, Oryza sativa L. with rice, O. Sativa. Weed Sci., 33: 644-649.

Division des Etudes Agronomique, Ministère de l'Agriculture. 1969. Le Riz au Tchad; Document $n^{\circ} 6 / 69$.

Ferrero A, Finassi A. 1995. Viability and soil distribution of red rice (Oryza sativa L. var. sylvatica) seeds. Med. Fac. Landbouww., Rijksunv. Gent., 5: 205-11.

Ferrero A, Vidotto F. 1997. Influence of soil tillage on red rice emergence. Med. Fac. Landbouww., Rijksunv. Gent., 7: 85-90.

Gaouna BO, Ponteutelbé E, Dar G. 2005. Rapport de prospection et collecte de riz dans les zones rizicoles des Régions de la Tandjilé et de Mayo-Kebbi Ouest 20p.

Gaouna BO, Weitar G, Dar G. 2006. Rapport de prospection et collecte de riz dans les zones rizicoles des Régions de la Tandjilé et de Mayo-Kebbi Ouest 16p.

Gaouna BO, Djingué A. 2007. Rapport de mission sur l'estimation des infestations des mauvaises herbes dans les rizières des zones de Bongor et de Kim, Marba, Béré et Laï. 13p.

Ghesquière A. 1991. Reexamination of the genetic control of the reproductive barrier between $O$. longistaminata and $O$. sativa and relationship with the rhizome expression. In Rice genetic II. Proc. of the 2"" Int. Rice Genet. Symp. IRRI, Les Banës, Philippines. 14-18 mai 1990, 729730.

Harlan JR, De Wet JMJ, Price EG. 1973. Comparative evolution of cereals. Evolution, 27: 311-325.
Kochko A. 1987. Isozymic variability of traditional rice varieties (Oryza saliva L.) in Africa. Theor. Appl. Genet., 73: 675682.

Maiko A, Jun U, Hiroyoshi I, Ryuji I, Toshio I. 2009. Genetic relationships and diversity of weedy rice (Oryza sativa L.) and cultivated rice varieties in Okayama Prefecture, Japan. Breeding Science, 59(4): 401-409.

Miezan K. Ghesquière A. 1986. The genetic structure of African traditional rice cultivars. In Rice Genetic. Proc. Int Rice Genet Symp. IRRI, Los BanDs, Philippines.27-31 mai 1985, 91-107.

Morishima H, Sano Y, Oka HI. 1992. Evolutionary studies in cultivated rice and its wild relatives. Oxford Surv. Evol. Biol., 8: $135-184$.

Morishima HO. 1998. Genetic difference between wild and cultivated rice. Agricultural Archaeology, 49(1): 30-35.

Naville M. 2005. La biodiversité des espèces cultivées : Analyse dans le cas du blé. In Travail Réalisé dans le Cadre des Projets Personnels Encadrés. ENS Cachan Département Biochimie et Génie Biologique, Université Paris XI.

Oka HI. 1958. Variétal variation and classification of cultivated rice. Ind. J. Genêt, PI. Bred., 18 : 78-89.

Oka HI. 1988. Origin of Cultivated Rice. Jnp. Sci. Soc. Press: Tokyo.

Parker C, Dean ML. 1976. Control of wild rice in rice. Pesticide Science, 7: 403-16.

Sano Y, Morishima H, Oka HI. 1980. Intermediate perennial - annual populations of Oryza perennis found in Thailand and their evolutionary significance. Bot. Mag. Tokyo, 93: 291305.

Smith RJ. 1981. Control of red rice (Oryza sativa) in water-seeded rice (O. sativa). Weed Science, 29: 663-666. 
Suh HS, Sato YI, Morishima H. 1997. Genetic characterization of weedy rice (Oryza sativa L.) based on morpho-physiology, isozymes and RAPD markers. Theoretical Applied Genetics, 94: 316-321.

Tang LH, Morishima H. 199. Genetic characterization of weedy rice and the inference on their origins. Breed. Sci., 47: 153-160.

Ushiki J, Ishii T, Ishikawa R. 2005. Morphophysiological characters and geographical distribution of japonica and indica weedy rice (Oryza sativa) in Okayama
Prefecture, Japan. Breed. Res., 7: 179187.

Vaughan DA, Zain AM. Watanabe H, Okuno K. 1993. Relationships between wild, weedy and cultivated rice in Malaysia. www.shigen.nig.ac.jp/rice/rgn/.../v12p18. html 